\title{
EVALUASI MUTU FISIK SEDIAAN KRIM HIDROKORTISON GENERIK DAN GENERIK BERLOGO
}

\author{
Puspita S \\ e-mail: raising.rahmawati@gmail.com \\ Prodi DIII Farmasi Stikes Bhakti Husada Mulia Madiun; \\ Jalan Taman Praja No 25 Madiun, telp/fax (0351) 491947
}

\begin{abstract}
Abstrak
Hidrokortison asetat adalah glukokortikoida yang banyak digunakan sebagai antiinflamasi lokal akibat dermatitis. obat tersebut banyak diformulasi sebagai sediaan krim. Obat generik merupakan obat yang telah habis masa patennya sehingga dapat diproduksi oleh semua perusahaan farmasi tanpa perlu membayar royalty Sedangkan Obat Generik Berlogo (OGB) merupakan program Pemerintah dengan tujuan memberikan alternatif obat bagi masyarakat, yang dengan kualitas terjamin, harga terjangkau, serta ketersediaan obat yang cukup. Penelitian dilaksanakan dilaboratorium kimia Stikes Bhakti Husada Mulia Madiun. Beberapa Hidrokortison generik dan generik berlogo disiapkan kemudian dilakukan uji evalusi mutu fisik yaitu berdasarkan Organoleptis, Uji Homogenitas, Uji pH, Uji Daya Sebar dan Viskositas krim. Berdasarkan hasil organoleptis hasil yang didapatkan berupa sediaan setengah padat, warna putih Aroma atau bau dan warna yang adalah tidak berbau. Uji homogenitas dimana hasil dari pengujian semua sediaan menunjukkan susunan yang homogen dan tidak terlihat adanya butiran kasar pada gelas objek. Berdasarkan Hasil pengkuran $\mathrm{pH}$ pada semua sediaan sesuai dengan $\mathrm{pH}$ kulit. Selanjutnya dilakukan uji daya sebar dimana Uji daya sebar krim berguna untuk mengetahui kemampuan menyebar krim saat di aplikasikan pada kulit. Krim hidrokortison krim generik dan generik berlogo dilakukan pengujian viskositas krim menggunakan viskometer. Hasil pengukuran viskositas pada sediaan menunjukan pada G1 memiliki viskositas paling tinggi pada G2, G3, GB1, GB2 dan GB3 dari minggu pertama hingga minggu kedua mengalami peningkatan Hasil penelitan ini menunjukkan tidak terdapat perbedaan antara hidrokortison krim generik dan generik berlogo pada evalusi mutu fisik.
\end{abstract}

Kata kunci: Hidrokortison krim generik, Hidrokortison krim

\section{Pendahuluan}

Obat antiinflamasi dibagi menjadi dua golongan yaitu antiinflamasi steroid (kortikosteroid) dan obat antiinflamasi non steroid. Di antara obat obatan topikal, kortikosteroid paling banyak digunakan karena kortikosteroid mempunyai daya vasokonstriksi kapiler, antiinflamasi dan antimitosis sehingga berperan penting dalan dermatologi. Hidrokortison asetat adalah glukokortikoida yang banyak digunakan sebagai antiinflamasi lokal akibat dermatitis [1]

Krim adalah bentuk sediaan setengah padat mengandung satu atau lebih bahan obat terlarut atau terdispersi dalam bahan dasar yang sesuai, atau bentuk sediaan setengah padat berupa emulsi yang mengandung satu atau lebih bahan obat terlarut, terdispersi dalam bahan dasar yang sesuai (mengandung air yang tidak kurang $60 \%)^{[2]}$. Penggunaan sediaan krim juga dapat memberikan efek dingin, mengkilap dan melembabkan kulit. Sediaan krim tipe M/A dibuat dengan cara mendispersikan minyak dan air. Keunggulan kim tipe M/A yaitu memberikan efek yang optimum karena mampu menaikkan gradien konsentrasi zat aktif yang menembus kulit sehingga absorbsi perkutan menjadi meningkat ${ }^{[3]}$

Hidrokortison asetat merupakan golongan kortikosteroid yang mempunyai efek farmakologi sebagai anti inflamasi atau antiradang akibat penyakit kulit yang responsif terhadap kortikosteroid. Kortikosteroid bekerja dengan cara mencegah reaksi alergi dengancara mencegah reaksi alergi dengan cara mencegah reaksi alergi, mengurangi peradangan, dan menghambat sel epidermis. Kortikosteroid topikal dapat diserap melalui kulit mutu normal. Adanya radang atau penyakit lain di kulit dapat meningkatkan absorpsi memalui kulit. Penggunaan sediaan ini yaitu dengan cara dioleskan 1-2 kali 
sehari pada bagian yang mengalami peradangan ${ }^{[4]}$. .

Produk obat yang beredar di Indonesia terdiri dari produk obat paten atau produk dengan nama dagang (bermerek) dan generik berlogo Obat generik merupakan obat yang telah habis masa patennya sehingga dapat diproduksi oleh semua perusahaan farmasi tanpa perlu membayar royalti. Obat generik memiliki efektivitas yang sama dengan obat paten, namun memiliki harga yang jauh lebih murah. Karena harganya yang murah, obat generik merupakan obat yang paling terjangkau bagi masyarakat menengah ke bawah, Kandungan zat aktif di dalam obat generik dan obat paten sama, sehingga masyarakat tidak perlu meragukan obat generikjadi kesimpulannya Obat generik adalah obat yang telah habis masa patennya dan kemudian dapat diproduksi oleh industri ang berbeda dari perusahan inovator

Sedangkan Obat Generik Berlogo (OGB) merupakan program Pemerintah Indonesia yang diluncurkan pada 1989 dengan tujuan memberikan alternatif obat bagi masyarakat, yang dengan kualitas terjamin, harga terjangkau, serta ketersediaan obat yang cukup. Tujuan OGB diluncurkan untuk memberikan alternatif obat yang terjangkau dan berkualitas kepada masyarakat. Soal mutu, sudah tentu sesuai standar yang telah ditetapkan karena diawasi secara ketat oleh Pemerintah. Awalnya, OGB diproduksi hanya oleh beberapa industri farmasi BUMN. OGB mudah dikenali dari logo lingkaran hijau bergaris-garis putih dengan tulisan "Generik" di bagian tengah lingkaran. Logo tersebut menunjukan bahwa OGB telah lulus uji kualitas, khasiat dan keamanan sedangkan garis-garis putih menunjukkan OGB dapat digunakan oleh berbagai lapisan masyarakat.

Yang harus diuji pada evaluasi mutu fisik adalah sebagai berikut : Organoleptis, Uji Homogenitas, Uji pH, Uji Daya Sebar, Viskositas krim. Sediaan krim yang baik yaitu sediaan krim yang stabil daya lekat dan daya sebarnya dan tidak adanya perubahan pada homogenitas, bau dan warna $\mathrm{pH}$ dan viskositas sediaan.
Berdasarkan uraian di atas maka dapat dirumuskan permasalahan Apakah pada evaluasi mutu fisik sediaan krim hidrokortison generik berbeda dengan hidrokortison generik berlogo?

Penelitian ini bertujuan untuk mengetahui mutu sediaan hidrokortison krim generik dan generik berlogo..

\section{Metode Penelitian}

Penelitian dilaksanakan dilaboratorium kimia Stikes Bhakti Husada Mulia Madiun dan jalannya penelitian ini terbagi dalam beberapa tahap, yakni tahap persiapan, tahap pelaksanaan, dan tahap pengelolaan data.

Tahap persiapan meliputi penyiapan bahan dan alat yang terdiri dari hidrokortison krim generik dan hidrokortison generik berlogo, kertas $\mathrm{pH}$ dan alat gelas objek. Alat $\mathrm{pH}$, cawan petri dan viscometer.

Pada tahap Pelaksanaan beberapa Hidrokortison generik dan generik berlogo disiapkan kemudian dilakukan uji evalusi mutu fisik yaitu berdasarkan Organoleptis, Uji Homogenitas, Uji pH, Uji Daya Sebar dan Viskositas krim.

a. Organoleptis

Uji organoleptis dimaksudkan untuk melihat tampilan fisik sediaan yang meliputi bentuk, warna dan bau.

b. Uji Homogenitas

Pemeriksaan homogenitas dilakukan dengan menggunakan gelas objek. Dimana sediaan dioleskan pada gelas objek tersebut.

c. Uji pH

Penenntuan $\mathrm{pH}$ dilakukan dengan menggunakan alat $\mathrm{pH}$ meter. Pengukuran dilakukan sebanyak tiga kali untuk masing-masing sediaan pada saat sediaan selesai dibuat dan penyimpanan selama 4 minggu.

\section{d. Uji Daya Sebar}

Timbang 0,5 gram krim, lalu letakan krim tersebut ditengah cawan petri yang berada dalam posisi terbalik. Beri beban cawan petri yang lain diatas krim lalu diamkan selama 1 menit. Tambahkan 50 gram beban lalu ukur diameternya. 
e. Viskositas krim

Pengukuran viskositas dilakukan dengan menggunakan viscometer brookfield.

\section{Hasil dan pembahasan}

Hidrokortison krim generik dan generik berlogo yang disiapkan masing-masing 3 tube dari pabrikan yang berbeda kemudian dilakukan evaluasi mutu fisik maka hasil yang didapatkan semua krim hidrokortison baik yang generik maupun generik berlogo mempunyai hasil yang hampir sama baik secara organoleptis yang dimaksudkan untuk melihat tampilan fisik sediaan yang meliputi bentuk, warna dan bau. Berdasarkan hasil yang didapat berupa setengah padat, warna putih Aroma atau bau dan warna yang adalah tidak berbau. Berdasarkan hasil pengamatan organoleptis diketahui bahwa semua sediaan tidak mengalami perubahan dari konsistensi bentuk, warna, maupun aroma atau bau dari awal pembuatan hingga selama penyimpanan 4 minggu. Artinya bahwa sediaan baik secara fisik.

Uji homogenitas bertujuan untuk melihat dan mengetahui tercampurnya bahan - bahan sediaan krim. Hasil Setiap formula krim tidak diperolehnya butiranbutiran kasar, maka semua formula sediaan krim dikatakan homogen. Uji Homogenitas dari semua sampel yang dilakukan dengan menggunakan gelas objek dimana hasil dari pengujian semua sediaan menunjukkan susunan yang homogen dan tidak terlihat adanya butiran kasar pada gelas objek.

Kemudian krim hidrokortison baik generik maupun generik berlogo diukur $\mathrm{pH}$ menggunaan alat $\mathrm{pH}$ meter, Uji $\mathrm{pH}$ bertujuan mengetahui keamanan sediaan krim saat digunakan sehingga tidak mengiratasi kulit. Berdasarkan Hasil pengkuran $\mathrm{pH}$ pada semua formula sediaan telah sesuai dengan $\mathrm{pH}$ kulit. karena $\mathrm{pH}$ tidak boleh terlalu asam karena dapat mengiritasi kulit dan tidak boleh terlalu basah karena sapat membuat kulit menjadi bersisik. Penurunan $\mathrm{pH}$ dapat dipengaruhi oleh suhu, kandungan zat lain dalam sediaan yang ikut bereaksi yang dapat menggangu [5].
Selanjutnya dilakukan uji daya sebar dimana Uji daya sebar krim berguna untuk mengetahui kemampuan menyebar krim saat di aplikasikan pada kulit. adanya penambahan beban menyebabkan diameter penyebaranya juga semakin besar sehingga semakin besar luas penyebaranya.

Tabel 1.Uji daya sebar

\begin{tabular}{|c|c|c|c|c|}
\hline \begin{tabular}{|l} 
Beban $50 \mathrm{~g}$ \\
Sediaan \\
\end{tabular} & & & & \\
\hline uas $(\mathrm{cm}) \mathrm{me}$ & gu k & & & \\
\hline 1 & 2 & 3 & 4 & \\
\hline G15,3 & 5,5 & 5.7 & 6,2 & \\
\hline G25,5 & 5,5 & 6 & 6,1 & \\
\hline G35,1 & 5.3 & 5.6 & 5.6 & \\
\hline GB1 & 4 & 4 & 4,2 & 4 \\
\hline GB2 & 4 & 4 & 4,1 & 4 \\
\hline GB3 & 4 & 4 & 4,2 & 4 \\
\hline
\end{tabular}

Berdasarkan tabel 1. Diameter penyebaran krim dikatakan baik daya sebarnya yaitu pada formula G2 dan G3 karena lebih besar dari pada krim G1. dibandingkan dengan konsentrasi GB1, GB2 dan GB3 yang tidak mengalami perubahan daya sebar.

Krim hidrokortison krim generik dan generik berlogo dilakukan pengujian viskositas krim menggunakan viskometer. Hasil pengukuran viskositas pada sediaan menunjukan pada G1 memiliki viskositas paling tinggi pada G2, G3, GB1, GB2 dan GB3 dari minggu pertama hingga minggu kedua mengalami peningkatan hal ini dapat disebabkan oleh penentu kekentalan dan penentu vikositas pada sediaan krim adalah bahan-bahan yang digolongkan dalam fase minyak terutama asam stearat dan setil alkohol. Bahan - bahan ini merupakan pengganti lemak karena memiliki karakteristik padat pada suhu ruangan ${ }^{[6]}$. sedangkan pada minggu ketiga mengalami penurunan tetapi tidak terlalu besar. mengalami penurunan viskositas yang terlalu besar hal ini dapat disebabkan oleh temperatur suhu yang tidak terkontrol, kemasan yang kurang kedap menyebabkan krim menyerap uap air dari luar, sehingga menambah volume air pada krim yang akan 
menurunklan nilai viskositas krim, faktor lain yang membuat krim menurun adalah adanya penambahan konsentrasi ekstrak sehingga nilai viskositas yang dihasilkan menurun.

\section{Kesimpulan}

Berdasarkan hasil dalam penelitian ini dapat disimpulkan bahwa tidak terdapat perbedaan antara hidrokortison krim generik dan generik berlogo pada evalusi mutu fisik.

\section{Daftar Pustaka}

[1] Ritter, J.M., Lewis, L.D., Mant, T.G., and Ferro,L. (2008). A Textbook of Clinical Pharmacology and Therapeutics (5th ed). Hodder Arnold, 338 Euston Road, London, p. $413-414$

[2] Depkes RI, 2014, Farmakope Indonesia Edisi V. Jakarta: Direktorat Jenderal Pengawasan Obatdan Makanan Departemen Kesehatan RI.

[3] Engelin., 2013, Optimasi Krim Sarang Burung Walet Putih Tipe M/A Dengan Variasi Emulgator Sebagai Pencerah Kulit Menggunakan Simplex Lattice Design, Skripsi, Fakultas Kedokteran, Universitas Tanjungpura Pontianak.

[4] BNF. (2009). British National Formulary. BMJ Group

[5] Deruje, H., Kaushik, D., Gupta, M., Kumar, V., Lather, V., 2005. Cosmeceutical: An Emerging Concept, Indian J Pharmacol., Hal 67.

[6] Rahmanto, A, 2011, Pemanfaatan Minyak Jarak Pagar (Jatropha corcus, Linn) Sebagai Komponen Sediaan Dalam Formulasi Produk Hand and Body Cream, Skripsi, Fakultas FMIPA. Institut Pertanian Bogor, Bogor. Hal 28. 